\title{
Analisis Pengaruh Current Ratio, Return on Equity dan Debt to Equity Ratio Terhadap Return Saham Pada Perusahaan Sub Sektor Telekomunikasi yang Terdaftar di Bursa Efek Indonesia Periode 2015-2019
}

\author{
Elida Gultom ${ }^{1}$, Kartika Sari Lubis ${ }^{2, *}$ \\ ${ }^{1}$ Sekolah Tinggi Ilmu Ekonomi Riau, Pekanbaru, Indonesia \\ ${ }^{2}$ Sekolah Tinggi Ilmu Manajemen Sukma, Medan, Indonesia \\ Email: ${ }^{1}$ elidagultom@lecturer.stieriau-akbar.ac.id, ${ }^{2,}{ }^{*}$ kartika@stimsukmamedan.ac.id
}

\begin{abstract}
Abstrak-Tingginya kebutuhan jaringan telekomunikasi dan data internet pada masyarakat, menyebabkan perusahaan-perusahaan telekomunikasi menjadi salah satu target bagi para investor, namun tidak semua perusahaan dapat memberikan return saham sesuai dengan yang diharapkan. Penelitian ini bertujuan untuk mengetahui pengaruh current ratio, return on equity dan debt to equity ratio terhadap return saham baik secara simultan maupun secara parsial pada perusahaan Sub Sektor Telekomunikasi yang terdaftar di Bursa Efek Indonesia Periode 2015 - 2019. Populasi dalam penelitian ini adalah seluruh perusahaan Sub Sektor Telekomunikasi yang terdaftar di Bursa efek Indonesia (BEI) Periode 2015-2019 yang berjumlah 6 perusahaan. Sampel dilakukan dengan teknik purposive sampling dengan sampel sebanyak 4 perusahaan. Metode penelitian ini menggunakan penelitian survey dengan pendekatan kuantitatif. Teknik analisis data yang digunakan adalah Regresi Linear Berganda. Kesimpulan dari penelitian ini adalah secara simultan current ratio, return on Equity dan debt to equity ratio berpengaruh signifikan terhadap return saham. Current ratio dan Dept to equity ratio (DER) tidak berpengaruh terhadap return saham sedangkan return on Equity (ROE) berpengaruh terhadap return saham. Besarnya pengaruh current ratio, return on equity (ROE) dan debt to equity ratio terhadap return saham sebesar 43,3\%. Dan variabel yang paling berpengaruh terhadap return saham pada perusahaan Sub Sektor Telekomunikasi di Bursa Efek Indonesia (BEI) periode tahun 2015 sampai tahun 2019 adalah return on equity $(R O E)$. Diharapkan perusahaan Sub Sektor Telekomunikasi meningkatkan kinerja keuanganya sehingga dapat meningkatkan return saham perusahaan.
\end{abstract}

Kata Kunci: Return Saham; Current Ratio; Return on Equity; Debt to Equity Ratio

\begin{abstract}
The high demand for telecommunications networks and internet data in the community has caused telecommunications companies to become one of the targets for investors, but not all companies can provide stock returns as expected. This study aims to determine the effect of the current ratio, return on equity and debt to equity ratio on stock returns either simultaneously or partially in Telecommunication Sub-sector companies listed on the Indonesia Stock Exchange for the 2015-2019 period. The population in this study are all Sub-sector companies. The Telecommunications sector listed on the Indonesia Stock Exchange (IDX) for the 2015-2019 period, amounting to 6 companies. The sample was carried out by purposive sampling technique with a sample of 4 companies. This research method uses survey research with a quantitative approach. The data analysis technique used is Multiple Linear Regression. The conclusion of this study is that the current ratio, return on equity and debt to equity ratio simultaneously have a significant effect on stock returns. Current ratio and Dept to equity ratio (DER) have no effect on stock returns, while return on equity (ROE) has no effect on stock returns. The magnitude of the influence of the current ratio, return on equity (ROE) and debt to equity ratio on stock returns is $43.3 \%$. And the variable that has the most influence on stock returns in Telecommunication Sub-Sector companies on the Indonesia Stock Exchange (IDX) for the period 2015 to 2019 is return on equity (ROE).
\end{abstract}

Keywords: Return Saham; Current Ratio; Return on Equity; Debt to Equity Ratio

\section{PENDAHULUAN}

Investasi merupakan suatu penanaman modal yang digunakan untuk meningkatkan keuntungan dengan menanamkan modal tersebut, dapat diprediksi memberikan keuntungan, (Fahmi, 2012). Salah satu investasi yang ditawarkan oleh perusahaan adalah saham di pasar modal. Pasar modal merupakan tempat bertemunya calon investor dengan pihak yang membutuhkan dana untuk memperjualbelikan sekuritas dalam waktu jangka panjang atau lebih dari satu tahun, (Tandelilin, 2010). Investasi pada pasar modal adalah investasi yang bersifat jangka pendek. Dapat dilihat dari return yang diukur dengan capital gain. Dengan membeli saham di pasar modal, investor mendapat keuntungan yang tinggi, tetapi untuk mendapatkan return saham yang tinggi juga memiliki ketidakpastian dan resiko yang tinggi dalam menentukan return saham menyebabkan sulit diprediksi oleh investor. Return adalah keuntungan yang diterima oleh investor atas investasi yang lakukannya. Tingkat keuntungan yang diterima oleh investor dinamakan dengan istilah return saham, yang mana bersumber dari yield, dividen dan capital gain. Harga saham yang diterima diakhir periode lebih besar dari harga saham pada saat awal periode, maka investor akan menerima capital gain dan sebaliknya jika harga saham yang diterima diakhir periode lebih rendah dari harga awal periode maka, investor menerima capital loss. (Indah Puspitadewi \& Rahyuda, 2016). Dalam menentukan kebijakan dividen, ada beberapa faktor yang harus diperhatikan yaitu: operating cash flow, tingkat laba, kesempatan investasi, biaya transaksi dan pajak penghasilan. (Husnan, 2008). Kebijakan dividen dipengaruhi oleh undang-undang. Posisi likuiditas, kebutuhan pelunasan hutang, tingkat ekspansi aktiva, tingkat laba, stabilitas laba, akses kepasar modal dan kendali perusahaan (Weston dan Copeland, 2013). Sedangkan menurut Sinuraya (2010) kebijakan dividen dipengaruhi oleh peraturan hukum, posisi 
likuiditas, pembayaran pinjaman, kontrak pinjaman yang terbatas, harta, tingkat keuntungan, stabilitas keuntungan, laba yang diperoleh serta pintu pasaran modal. Pertumbuhan teknologi jaringan dan telekomunikasi tubuh dengan pesat dalam Bursa Efek Indonesia. Perusahaan sub sektor telekomunikasi salah satu sektor investasi yang diminati masyarakat. Sub Sektor Telekomunikasi yang terdaftar di BEI hingga tahun 2020 adalah sebanyak 6 perusahaan yaitu; PT. Bakrie Telecom, Tbk, PT. XL Axiata, Tbk, PT. Smartfren Telecom,Tbk, PT. Jasnita Telekomindo,Tbk, PT.Indosat,Tbk dan PT.Telekomunikasi Indonesia,Tbk.

Tabel 1. Perkembangan Return Saham Perusahaan Sub Sektor Telekomunikasi Periode 2015 -2019 (dalam persen)

\begin{tabular}{|c|c|c|c|c|c|c|c|}
\hline \multirow{2}{*}{ No } & \multirow{2}{*}{$\begin{array}{c}\text { Nama } \\
\text { Perusahaan }\end{array}$} & \multirow{2}{*}{ Kode } & \multicolumn{5}{|c|}{ Return Saham/Tahun (\%) } \\
\hline & & & 2015 & 2016 & 2017 & 2018 & 2019 \\
\hline 1 & PT. XL Axiata Tbk & $\mathrm{EXCL}$ & -23.93 & -36.71 & 28.13 & -33.10 & 59.09 \\
\hline 2 & PT. Smartfren Tbk & FREN & -43.95 & 3.92 & -5.64 & 56.60 & 76.92 \\
\hline 3 & PT. Indosat Tbk & ISAT & 35.80 & 17.27 & -25.58 & -64.90 & 72.70 \\
\hline 4 & $\begin{array}{l}\text { PT. Telekomunikasi } \\
\text { Indonesia Tbk }\end{array}$ & TLKM & 8.38 & 28.18 & 11.56 & -15.50 & 5.86 \\
\hline \multicolumn{3}{|c|}{ Rata-rata Return Saham } & -5.93 & 3.17 & 2.12 & -14.23 & 53.64 \\
\hline
\end{tabular}

Sumber: $w w w$. finance.yahoo.com (data diolah)

Sub Sektor Telekomunikasi merupakan salah satu sub sektor yang bertahan saat ini dan bahkan sudah menjadi kebutuhan utama masyarakat. Rata-rata return saham perusahaan Sub Sektor Telekomunikasi selama tahun 2015-2019 cenderung berfluktuasi dan ditahun 2019 meningkat tajam. Berdasarkan data diatas dapat dibuktikan bahwa tidak ada kepastian mengenai return saham yang diperoleh oleh investor dalam berinvestasi saham, untuk itu invester perlu mempertimbangkan secara rasional dalam mengumpulkan berbagai informasi dan data dalam mengambil keputusan investasi. Tapi disisi lain beberapa penilaian investor terhadap ivestasi saham yaitu prospek dari usaha atau yang begitu menjanjikan, kinerja financial dan non financial yang menggiurkan serta, adanya laporan keuangan yang jelas dan transparan dan adanya keuntungan (return) yang terus meningkat. (Fahmi, 2015).

Banyak faktor yang mempengaruhi perubahan harga saham, sehingga membuat investor tidak salah dalam menganalisa arah pasar. Salah satu teknik dalam bertransaksi yang banyak dipergunakan investor adalah analisis ekonomi/pasar atau pendekatan fundamental, dilanjutkan dengan analisis industry dan kemudian analisis terhadap pasar (Husnan, 2008). Dalam tahap pendekatan fundamental, salah satu aspek penilaian yang digunakan adalah kinerja keuangan. Mengukur keuangan perusahaan melalui rasio-rasio keuangan yaitu rasio likuiditas, rasio solvabilitas, rasio profitabilitas, rasio aktivitas dan rasio penilaian pasar.(Indah Puspitadewi \& Rahyuda, 2016).

Dalam penelitian ini membahas tentang rasio likuiditas yaitu current ratio, rasio solvabilitas yaitu debt to equity ratio dan rasio profitabilitas yaitu return on equity. Untuk mengukur current ratio, pembilangnya mengandung persediaan relative sukar ditentukan secara tepat kapan menjadi uang kas. Oleh karena itu, banyak yang menganggab current ratio kurang dapat mencerminkan likuiditas perusahaan. (Alexandri, 2008). Nilai current ratio yang tinggi menunjukkan kewajiban yang tinggi dapat dilunasi dengan adanya ketersediaan aktiva lancar tetapi nilai current ratio yang tidak menjamin perusahaan mempunyai kas yang cukup dalam membayar hutang lancarnya. (Tumonggor dkk, 2017). Return on equity (ROE) atau laba atas ekuitas. Rasio ini, digunakan untuk mengetahui sejauh mana perusahaan kemampuan ekuitas yang dimiliki untuk mampu memberikan keuntungan (Fahmi, 2012). Berdasarkan hasil penelitian terdahulu yang dilakukan oleh Andansari dkk (2016), menemukan bahwa return on equity (ROE) berpengaruh positif terhadap return saham. Dan sebaliknya hasil penelitian dari Junaidi (2012) menunjukkan return on equity (ROE) tidak berpengaruh signifikan terhadap return saham.

Dept to equity ratio (DER), digunakan untuk menilai banyaknya hutang yang digunakan perusahaan. Semakin rendah hasil dari rasio tersebut menunjukkan semakin tinggi tingkat pembelanjaan perusahaan yang disediakan oleh pemegang saham dan semakin besar tingkat perlindungan kreditur dari kehilangan uang yang diinvestasikan ke perusahaan tersebut, (Alexandri, 2008). Tingginya nilai DER akan mencerminkan tingginya hutang perusahaan, hal ini menunjukkan hutang lebih besar komposisinya dibandingkan dengan ekuitas yang dimiliki perusahaan mengakibatkan meningkatnya resiko yang ditanggung oleh investor karena beban bunga hutang. Hal ini bisa berakibat turunnya harga saham dan akan berdampak terhadap return saham. (Arista \& Astohar, 2012). Pandangan yang berbeda terhadap Dept to equity ratio. Perusahaan yang memiliki hutang yang tinggi jika digunakan secara maksimal dalam mengelola asset, maka kemungkinan penjualan perusahaan akan meningkat, dengan demikian perusahaan akan memperoleh keuntungan yang akan semakin tinggi sehingga bisa menarik minat investor untuk melakukan investasi dan secara otomatis akan terjadi peningkatan terhadap harga saham serta return saham (Sari \& Hutagaol, 2009).

\section{KERANGKA TEORI}

\subsection{Return Saham}


Pengertian saham adalah 1) tanda bukti kepemilikan modal pada perusahaan, 2) kertas yang tercantum dengan jelas nilai nominal, nama perusahaan yang disertai hak dan kewajiban kepada pemegangnya dan 3) persediaan yang siap untuk dijual.(Fahmi, 2015). Return Saham adalah hasil bagi antara selisih harga saham periode tahun depan dengan harga saham periode saat ini dibagi harga saham periode saat ini.(Basalama, Murni, \& Sumarauw, 2017). Tingkat pengembalian saham yang diberikan kepada investor (Harjono, 2010) dengan rumus sebagai berikut:

$$
R_{t}=\frac{P_{t}-P_{t-1}}{P_{t-1}}
$$

Ket:

$$
\begin{aligned}
& \mathrm{R}_{\mathrm{t}}=\text { Return saham } \\
& \mathrm{P}_{\mathrm{t}}=\text { Harga saham sekarang } \\
& \mathrm{P}_{\mathrm{t}-1}=\text { Harga saham periode lalu }
\end{aligned}
$$

\subsection{Current Ratio}

Current Ratio adalah kemampuan perusahaan dalam memenuhi utang saat jatuh tempo atau utang jangka pendeknya (Fahmi, 2015) dengan rumus sebagai berikut

$$
\text { Current Ratio }=\frac{\text { Current Assets }}{\text { Current liabilities }}
$$

\subsection{Return on Equity}

Return On Equity (X2) adalah rasio digunakan untuk mengukur sejauh mana kemampuan perusahaan dalam menghasilkan laba atas ekuitas (Fahmi, 2015). Adapun rumus ROE adalah sebagai berikut:

$$
\mathrm{ROE}=\frac{E A T}{\text { Shareholders' Equity }} \times 100 \%
$$

\subsection{Debt to Equity Ratio}

Debt To Equity Ratio (X3), menurut Joel G Siegel dan Jae K Shim yaitu rasio yang digunakan untuk menganalisis laporan keuangan untuk memperlihatkan besarnya jaminan yang tersedia (Fahmi, 2015)

\subsection{Kerangka Konsep}

$$
\text { Debt To Eguity Ratio (X3) }=\frac{\text { Total Liabilitie } s}{\text { Total shareholde } r s^{\prime} \text { Equity }} \times 100 \%
$$

Adapun alur dari analisis data tersebut adalah seperti pada gambar berik=ut ini:

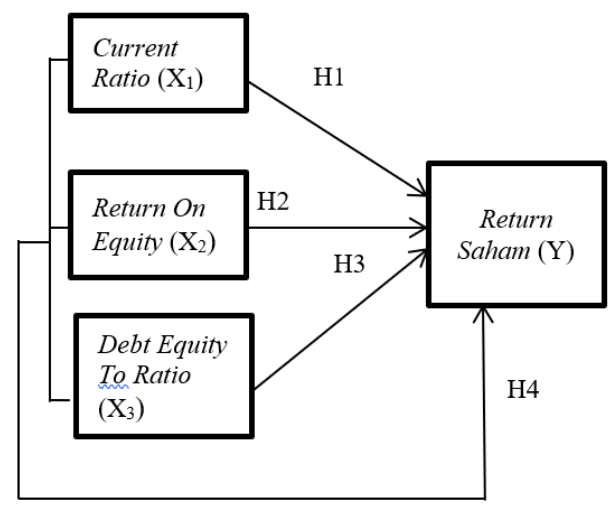

Gambar 1. Kerangka Konsep

\subsection{Hipotesis}

Berdasarkan rumusan masalah penelitian maka hipotesis dalam penelitian ini adalah sebagai berikut:

H1 : Diduga current ratio, return on equity, dan debt to equity ratio secara simultan berpengaruh signifikan terhadap return saham

H2 : Diduga current ratio tidak berpengaruh signifikan terhadap Return Saham.

H3 : Diduga return on equity berpengaruh signifikan terhadap return saham 


\section{METODOLOGI PENELITIAN}

Jenis penelitian yang digunakan adalah penelitian survey dengan pendekatan kuantitatif. Populasi dalam penelitian ini adalah seluruh perusahaan Sub Sektor Telekomunikasi yang sudah terdaftar dan masih terdaftar di Bursa efek Indonesia periode 2015-2019 yang berjumlah 6 perusahaan antara lain: BTEL, EXCL, FREN, JAST, ISAT dan TLKM. Adapun sampel menggunakan teknik purposive sampling yaitu pengambilan sampel berdasarkan kriteria. Adapun kriterianya adalah 1) perusahaan telekomunikasi yang terdaftar di Bursa Efek Indonesia. 2) Tersedia data yang lengkap untuk memenuhi variabel penelitian dan 3) mempunyai laporan keuangan tahun buku yang berakhir per 31 Desember antara periode 2015 -2019. Berdasarkan kriteria tersebut maka perusahaan yang memenuhi kriteria sebanyak 4 perusahaan yaitu EXCL, FREN, ISAT, dan TLKM.

\subsection{Model Analisis Data}

Analisis data dalam penelitian ini adalah regresi linear berganda dengan persamaan:

$$
\mathrm{Y}=\mathrm{a}+\mathrm{b} 1 \mathrm{X}_{1}+\mathrm{b} 2 \mathrm{X}_{2}+\mathrm{b} 3 \mathrm{X}_{3}+\mathrm{e}
$$

Keterangan:

$\begin{array}{ll}\mathrm{Y} & =\text { return saham } \\ \mathrm{A} & =\text { konstanta } \\ \mathrm{B} & =\text { koefisien regresi } \\ \mathrm{X}_{1} & =\text { Current Ratio } \\ \mathrm{X}_{2} & =\text { Return On Equity }(\mathrm{ROE}) \\ \mathrm{X}_{3} & =\text { Debt to Equity Ratio }(\mathrm{DER})\end{array}$

\section{HASIL DAN PEMBAHASAN}

Berdasarkan kriteria-kriteria pengambilan sampel yang telah ditentukan, terdapat 4 (empat) perusahaan sampel yang terpilih dari daftar perusahaan Sub Sektor Telekomunikasi yang datanya sesuai dengan kebutuhan penelitian, sehingga dalam 5 tahun penelitian diperoleh 20 data pengamatan yang digunakan sebagai sampel dalam penelitian ini. Berikut nama-nama perusahaan yang menjadi sampel dalam penelitian ini.

Tabel 1. Nama-nama Perusahaan Sampel

\begin{tabular}{lll}
\hline No & Kode Saham & \multicolumn{1}{c}{ Nama Emiten } \\
\hline 1 & EXCL & XL Axiata, Tbk \\
2 & FREN & Smartfren, Tbk \\
3 & ISAT & Indosat, Tbk \\
4 & TLKM & Telekomunikasi \\
& & Indonesia, Tbk \\
\hline
\end{tabular}

Sumber: Hasil olah data, 2020

\section{a. Hasil Uji Asumsi Klasik}

1. Uji Normalitas

Untuk menguji kenormalan distribusi data, dalam penel tian ini yang digunakan adalah Uji Kolmogorov Smirnov. Data dikatakan berdistribusi normal apabila nilai Asymp.Sig (2-tailed) variabel residual berada diatas 0,05. Dan sebaliknya jika nilai Asymp.Sig (2-tailed) variabel residual berada dibawah 0,05. Maka data tersebut mengalami normalitas.

Tabel 2. Hasil Uji Kolmogrov Smirnov

\begin{tabular}{lc}
\hline Keterangan & $\begin{array}{c}\text { Unstandarzed } \\
\text { Residual }\end{array}$ \\
\hline $\mathrm{N}$ & 20 \\
Kolmogorov-Smirnov $Z$ & 0.119 \\
Asymp. Sig (2-tailed) & 0.200 \\
\hline
\end{tabular}

Sumber: Hasil Olah Data, 2020 
Berdasarkan hasil uji normalitas, menunjukan data terdistribusi normal dimana, besarnya nilai Kolmogorov-Smirnov $Z$ sebesar 0,119 dengan nilai Asymp.Sig (2-tailed) sebesar 0,200 jauh diatas $\alpha=0,05$ hal ini berarti data berdistribusi secara normal.

\section{Uji Multikolinieritas}

Uji multikolinieritas bertujuan untuk menguji model regresi ditemukannya adanya korelasi antar variabel bebas (independen) atau tidak. Model regresi yang baik tidak terjadi korelasi diantara variabel independen. Multikolineritas dapat dilihat dengan variance inlation factor (VIF) bila nilai VIF 0,10 maka tidak ada gejala Multikolinieritas. Berikut hasi uji multikolinearitas

Tabel 3. Hasil Uji Multikolinearitas

\begin{tabular}{lclc}
\hline Var & VIF & Tolerance & Keterangan \\
\hline CR & 1.235 & 0.810 & Tidak terjadi Multikolinieritas \\
ROE & 1.002 & 0.998 & Tidak terjadi Multikolinieritas \\
DER & 1.234 & 0.810 & Tidak terjadi Multikolinieritas \\
\hline
\end{tabular}

Sumber: Hasil olah Data, 2020

Hasil perhitungan nilai tolerance menunjukkan tidak ada variabel bebas yang memiliki nilai tolerance kurang dari 0.10 . Hal yang sama ditunjukkan oleh nilai VIF, dimana VIF kurang dari 10. Maka kesimpulan yang dapat diambil dari tabel 5.4 yaitu tidak terdapat multikolinieritas antar variabel bebas, sehingga model regresi layak digunakan.

3. Uji Autokorelasi

Berdasarkan hasil uji autokorelasi diperoleh nilai Durbin-Watson sebesar 2.338 sedangkan dari tabel Durbin-Watson dengan signifikansi 0,05 diperoleh di sebesar 0,9976 dan du sebesar 1,6763. Tidak terjadi autokorelasi jika du $<\mathrm{d}<4-$ du, maka dalam penelitian ini dapat dibuktikan bahwa nilai dw terletak diantara du dan 4-du. Data du sebesar 1,6763 sehingga 4-du adalah sebesar 2,3237 maka hasilnya 1,6763 <2,338<2,3231. Berdasarkan pengujian tersebut dapat disimpulkan bahwa model regresi pada penelitian ini tidak terjadi autokorelasi.

4. Uji Heteroskedastisitas

Hasil uji heteroskedastisitas dengan Glejser ditunjukkan dalam tabel berikut:

Tabel 4. Hasil Uji Heteroskedastisitas

\begin{tabular}{llll}
\hline Var & Sig & $\begin{array}{l}\text { Nilai } \\
\text { Kritis }\end{array}$ & Keterangan \\
\hline X1 & 0.09 & 0,05 & Homoskedastisitas \\
X2 & 0,215 & 0,05 & Homoskedastisitas \\
X3 & 0,762 & 0,05 & Homoskedastisitas \\
\hline
\end{tabular}

Sumber: Hasil Olah Data, 2020

Tabel di atas menunjukkan probability value (signifikansi) masing-masing variabel dependen, hasil regresi nilai absolute residual terhadap variabel independen diperoleh nilai signifikansi di atas tingkat signifikansi 0,05 dengan demikian dapat disimpulkan bahwa model regresi tidak terjadi heteroskedastisitas.

\section{b. Hasil Uji Regresi Linear Berganda}

Tabel 5. Hasil Uji Koefisien Regresi Berganda

\begin{tabular}{cccc}
\hline Variabel & $\begin{array}{c}\text { Koefiisen } \\
\text { Regresi }\end{array}$ & $\mathrm{T}$ & Sig \\
\hline Konstanta & 0.183 & 0.816 & 0.427 \\
$\mathrm{X}_{1}$ & -0.032 & -0.243 & 0.811 \\
$\mathrm{X}_{2}$ & 0.586 & 3.282 & 0.005 \\
$\mathrm{X}_{3}$ & -0.100 & -1.226 & 0.238 \\
\hline \multicolumn{3}{c}{ Koefisien Determinasi $\left(\mathrm{R}^{2}\right)$} & 0,433 \\
& F-Hitung & 4.070 \\
& Sig F & 0,025 \\
& F-tabel & 3.24 \\
\hline
\end{tabular}

Sumber: Hasil Olah Data, 2020 
Berdasarkan hasil regresi linier berganda, maka dapat disusun persamaan faktor-faktor yang mempengaruhi Return Saham yaitu: $\mathrm{Y}=0,183-0,032 \mathrm{X} 1+0,586 \mathrm{X} 2-0,100 \mathrm{X} 3$. Nilai koefisien $\mathrm{X} 1$ sebesar 0,183 yang berarti current ratio meningkat 1 satuan maka return saham akan turun sebesar -0,032 dengan asumsi X2, X3 tetap. Nilai koefisien X2 sebesar 0,586 yang berarti Return on Equity meningkat 1 satuan maka return saham akan naik sebesar 0,586 dengan asumsi X1, X2 tetap. Nilai koefisien X3 sebesar -0,100 yang berarti Debt to equity ratio meningkat 1 satuan maka return saham akan menurun sebesar -0,100 dengan asumsi X1, X2 tetap.

\section{c. Uji t (Parsial)}

1. Pengaruh Current ratio (X1) terhadap return saham (Y). Diperoleh nilai signifikansi sebesar 0,885 lebih besar dari nilai signifikansi yang ditetapkan sebesar 0,05 dengan demikian Ho diterima atau Ha ditolak, artinya current ratio (X1) tidak berpengaruh signifikan terhadap return saham (Y).

2. Pengaruh ROE (X2) terhadap Return Saham (Y). Berdasarkan hasil analisis diperoleh nilai signifikansi ROE (X2) sebesar $0,004<0,05$ nilai signifikansi yang ditetapkan. Dengan demikian Ho ditolak dan menerima Ha artinya hipotesis diterima, terbukti bahawa ROE (X2) berpengaruh signifikan terhadap return saham (Y).

3. Pengaruh DER (X3) terhadap Return Saham (Y). Diperoleh nilai signifikan DER (X3) sebesar $0.360>0.05$ nilai signifikan yang telah ditetapkan, dengan demikian dapat disimpulkan bahwa DER (X3) tidak berpengaruh signifikan terhadap return saham (Y) artinya Ho diterima dan menolak Ha.

\section{d. Uji F (Simultan)}

Berdasarkan tabel 5 diperoleh hasil F-hitung sebesar 4.070 dengan F-tabel sebesar 3.24 artinya F-hitung >F-tabel dengan niali signifikan sebesar $0,025<0,05$ hal ini menunjukkan bahwa current ratio, return on equity, debt to equity ratio secara simultan berpengaruh positif dan signifikan terhadap return saham.

\section{e. Uji Determinasi}

Berdasarkan hasil olah data diketahui nilai $\mathrm{R}^{2}=0.433$ yang artinya pengaruh carrent ratio $(\mathrm{X} 1)$, ROE (X2) dan DER (X3) secara bersama-sama terhadap return saham (Y) adalah sebesar 43,3\% Sedangkan sisanya 56,7\% dipengaruhi oleh variabel lain yang tidak dibahas dalam penelitian ini

\subsection{Pembahasan}

Penelitian ini bertujuan untuk mengetahui pengaruh current ratio $(C R)$, return on equity $(R O E)$ dan debt to equity ratio (DER) secara parsial maupun simultan terhadap return saham pada perusahaan sektor Telekomunikasi periode 2015-2019. Berdasarkan hasil analisis, berikut ini akan dijelaskan hasil dari penelitian:

Pengaruh current ratio terhadap return saham pada perusahaan Sub Sektor Telekomunikasi yang terdaftar di Bursa Efek Indonesia periode 2015 sampai 2019, dimana berdasarkan hasil penelitian secara parsial current ratio tidak berpengaruh signifikan terhadap return saham, hal ini ditunjukkan dengan nilai signifikansi current ratio sebesar 0.885 lebih besar dari 0.05 nilai signifikansi yang telah ditetapkan. Hasil penelitian ini sesuai dengan hasil penelitian dari (Basalama et al., 2017) dan (Erari, 2014) hasil penelitianya juga menyatakan bahwa current ratio berpengaruh negatif terhadap return saham. Dalam penelitian ini current ratio juga berpengaruh negatif terhadap return saham artinya nilai current ratio yang tinggi belum tentu bisa menghasilkan imbal balik return saham yang tinggi dan pembayaran utang akan terpenuhi apabila utang sudah jatuh tempo. Hal ini dapat disebabkan oleh nilai persediaan yang tinggi dibandingkan taksiran penjualan yang akan datang, sehingga akan menunjukkan kelebihan persediaan dan memperlihatkan perusahaan tidak memaksimalkan persediaan yang ada. Current ratio yang terlalu tinggi menunjukkan kelebihan aktiva lancar yang menganggur sehingga tidak baik bagi profitabilitas perusahaan karena aktiva lancar menghasilkan return yang lebih rendah dibandingkan aktiva tetap.(Hanafi, Mamduh M; Halim, 2012). Jika rasio lancar rendah, dapat disebabkan perusahaan memiliki modal yang kurang untuk membayar utang, namun bila perusahaan memiliki rasio yang tinggi belum tentu kondisi perusahaan sedang baik. Hal ini disebabkan karena asset tidak digunakan dengan sebaik mungkin.(Kasmir (2015:10), 2015).

Pengaruh return on equity (ROE) terhadap return saham pada Perusahaan sektor Telekomunikasi yang terdaftar di BEI periode 2015 sampai 2019. Hasil penelitian mendukung hipotesis kedua bahwa return on equity (ROE) berpengaruh positif dan signifikan terhadap return saham pada perusahaan sektor Telekomunikasi. Hal ini ditunjukkan dengan perhitungan analisis regresi hasil pengujian menunjukkan nilai signifkan $0.004<0,05$ nilai signifikan yang ditetapkan. Hasil penelitian terdahulu juga menemukan bahwa return on equity memiliki pengaruh positif terhadap return saham (Andansari, Raharjo, \& Andini, 2016). Return on equity yang tinggi memiliki arti bahwa perusahaan memaksimalkan ekuitasnya secara efektif dan efisien, dan sebaliknya ROE yang rendah menandakan perusahaan belum maksimal dalam menggunakan ekuitasnya. Semakin tinggi ROE dalam perusahaan hal ini memperlihatkan bahwa perusahaan sudah berhasil mengelola maupun memperdayakan ekuitasnya untuk menghasilkan laba yang tinggi. 
Pengaruh debt to equity ratio terhadap return saham pada perusahaan sektor telekomunikasi yang terdaftar di BEI periode 2015-2019. Hasil penelitian tidak mendukung hipotesis retur saham pada perusahaan sektor Telekomunikasi yang terdaftar di BEI periode 2015-2019. Hal ini ditunjukkan dengan perhitungan analisis regresi hasil pengujian menunjukkan nilai signifikansi 0,36>0,05 nilai signifikan yang ditetapkan. Hasil penelitian ini sesuai dengan hasil penelitian sebelumnya dimana Debt equity ratio berpengaruh negatif dan tidak signifikan terhadap return saham (Indah Puspitadewi \& Rahyuda, 2016). DER merupakan rasio yang digunakan untuk membandingkan modal sendiri dan modal yang didapat dari luar atau kreditur. Adanya ketidakmampuan perusahaan dalam menyiapkan modal sehingga perusahaan mencari modal dari pihak luar. Semakin besar DER menunjukkan struktur modal yang berasal dari utang untuk memenuhi ekuitas. Dan sebaliknya DER yang kecil akan semakin baik. Tingginya DER akan berdampak negatif dari sisi kreditur akan menilai resiko atas kegagalan membayar utang lebih besar, dan dari sisi investor menunjukkan kegiatan operasional perusahaan dari pinjaman atau utang lebih besar akan memperlihatkan kinerja perusahaan tidak baik, makan return saham akan menurun, sehinggan DER berpengaruh negatif terhadap return saham.

\section{KESIMPULAN}

Berdasarkan hasil analisis, dapat disimpulkan Current ratio dan Dept to equity ratio secara parsial tidak berpengaruh signifikan terhadap return saham sedangkan Return on equity berpengaruh positif dan signifikan terhadap return saham pada perusahaan sektor Telekomunikasi yang terdaftar di Bursa Efek Indonesia periode 2015-2019. Secara simultan current ratio, return on equity dan debt to equity ratio berpengaruh positif dan signifikan terhadap return saham dan terdapat $43,3 \%$ pengaruh current ratio, return on equity dan debt to equity ratio terhadap return saham Sub Sektor Telekomunikasi yang terdaftar di Bursa Efek Indonesia periode 2015-2019.

\section{DAFTAR PUSTAKA}

Alexandri, M. B. (2008). Manajemen keuangan bisnis teori \& soal. Alphabet, Bandung.

Andansari, N. A., Raharjo, K., \& Andini, R. (2016). Pengaruh ROE, PER, TATO dan PBV Terhadap Return Saham (Studi Kasus Pada Perusahaan Manufaktur Sektor Makanan dan Minuman yang Terdaftar di BEI Periode 2008-2014). Journal Of Accounting.

Arista, D., \& Astohar. (2012). Analisis Faktor - faktor yang Mempengaruhi Return Saham (Kasus pada Perusahaan Manufaktur yang Go Public di BEI periode tahun 2005 - 2009). Jurnal Ilmu Manajemen Dan Akuntansi Terapan.

Basalama, I. S., Murni, S., \& Sumarauw, J. S. B. (2017). Pengaruh Current Ratio, Der Dan Roa Terhadap Return Saham Pada Perusahaan Automatif Dan Komponen Periode 2013-2015. Jurnal EMBA.

Damasena, I., Blythe, M., Wysocki, D., Kelly, D., \& Annear, P. (2016). Medial Patellofemoral Ligament Reconstruction Combined With Distal Realignment for Recurrent Dislocations of the Patella: 5-Year Results of a Randomized Controlled Trial. The American Journal of Sports Medicine. https://doi.org/10.1177/0363546516666352

Erari, A. (2014). Analisis Pengaruh Current Ratio, Debt To Equity Ratio, dan Return On Asset Terhadap Return Saham Pada Perusahaan Pertambangan di Bursa Efek Indonesia. Jurnal Manajemen Bisnis Universitas Muhammadiyah Yogyakarta.

Fahmi, I. (2012). Manajemen Investasi: Teori dan Soal Jawab. Jakarta: Salemba Empat.

Fahmi, I. (2015). Manajemen Investasi Teori dan Soal Jawab. In Inflasi dan Investasi.

Hanafi, Mamduh M; Halim, A. (2012). Analisis Laporan Keuangan, Edisi Keempat. Yogyakarta: UPP STIM YKPN.

Harjono, S. (2010). Pengaruh Penilaian Kinerja dengan ROI dan EVA terhadap Return Saham pada Perusahaan yang Tergabung dalam Indeks LQ 45 di Bursa Efek Indonesia. Pengaruh Penilaian Kinerja Dengan ROI Dan EVA Terhadap Return Saham Pada Perusahaan Yang Tergabung Dalam Indeks LQ 45 Di Bursa Efek Indonesia.

Husnan, S. (2008). Dasar-dasar Teori Portofolio dan Analisis Sekuritas Ed: 4. In Yogyakarta (ID): Penerbit dan Percetakan UPP STIM $Y K P N$.

Indah Puspitadewi, C., \& Rahyuda, H. (2016). Pengaruh DER, ROA, PER Dan EVA Terhadap Return Saham Pada Perusahaan Food And Beverage Di BEI. E-Jurnal Manajemen Universitas Udayana.

Junaidi 2012. Pengaruh Rasio Keuangan Terhadap Return Saham Pada Perusahaan Otomotif yang Terdaftar di Bursa Efek Indonesia (BEI) Periode 2007-2011. Fakultas Ekonomi, Universitas Maritim Raja Ali Haji, Tanjungpinang.

Kasmir (2015:10). (2015). Pengertian Laporan Keuangan. Harahap (2015:105), .

Malintan, R. (2012). Pengaruh Current Ratio (CR), Debt To Equity Ratio (DER), Price Earning Ratio (PER), dan Return On Asset (ROA) Terhadap Return Saham Perusahaan Pertambangan yang Terdaftar di Bursa Efek Indonesia Tahun. Universitas Brawijaya.

Sari, L. A., \& Hutagaol, Y. R. I. (2009). Debt to equity ratio, degree of operating leverage stock beta and stock returns of food and beverages companies on the Indonesian stock exchange. Journal of Applied Finance \& Accounting, 2(1), 1-12.

Tandelilin, E. (2010). portofolio dan investasi. In Kanisius. 